\title{
Anatomy of 1,618
}

\author{
Nevra Yalcin \\ Başkent University, Faculty of Medicine, Term II Student, Ankara, Turkey \\ Gokce Sezen Aydin \\ Başkent University, Faculty of Medicine, Term II Student, Ankara, Turkey \\ Irem Tarinc \\ Başkent University, Faculty of Medicine, Term II Student, Ankara, Turkey \\ Melek Colakoglu \\ Başkent University, Faculty of Medicine, Term II Student, Ankara, Turkey \\ Elif Efsane Aslanoglu \\ Başkent University, Faculty of Medicine, Term I Student, Ankara, Turkey \\ Ayla Kurkcuoglu (Corresponding author) \\ Baskent University, Faculty of Medicine, Department of Anatomy, Ankara, Turkey \\ E-mail: kayla@baskent.edu.tr
}

\begin{abstract}
'Golden Ratio' or 'Golden Number' otherwise known as the Divine Proportion (Phi), is a mathematical ratio with special properties and aesthetic significance. "Fibonacci" had described a number series that led to a significant upheaval in our understanding of mathematical aspects of nature. This sequence, namely Fibonacci Series or Sequence, constitutes an infinite chain of numbers starting with ' 0 ' or ' 1 ' and following as $0,1,1,2,3,5,8,13,21,34 \ldots$ particularly implying that the sum of two consecutive integers equals the subsequent one. An enormous number of things in the universe are engineered around the ratio, ranging from the human body to the art of the covenant to snail shells to the orbits of the planets. It plays a vital role in the arrangement of petals in flowers, structure of DNA and various proportions in human face, structure of sea shells etc. Occurrence of this proportion in zoology is frequent, viz in the clock cycle of brain waves, in hearing and balance organ etc. The present review primarily aims to focus on human manifestations of divine aesthetics as demonstrated with 'Golden Ratio' and associated indiceswith a particular emphasis and detailed information on their association with the human body.
\end{abstract}

Key words: Golden ratio, golden number, human body, Fibonacci series

DOI: $10.7176 / \mathrm{JSTR} / 5-4-02$

\section{1,618'in Anatomisi}

\section{Özet}

İlahi Oran (Phi) olarak bilinen "Altın oran" veya "Altın Sayı", estetik önemi olan matematiksel bir orandır. "Fibonacci", doğadaki karışıklığa neden olan matematiksel oranları bir sayı dizisiyle tanımlamıştır. Art arda gelen iki sayının toplamı bir sonraki sayıyı verecek şekilde ilerleyen bu dizi, yani Fibonacci Serisi veya Dizisi, '0' veya '1' ile başlar ve $0,1,1,2,3,5,8,13,21,34 \ldots$ olarak sonsuza kadar devam eder. Evrendeki muazzam sayıda şey, insan bedeninden sanata, salyangoz kabuklarına ve gezegenlerin yörüngesine kadar uzanan bir oran etrafında işlenmiştir. Bu dizi çiçeklerde taç yaprakların düzeninde, DNA yapısında ve insan yüzünde çeşitli oranlarda, deniz kabuklarının yapısında, zoolojide de beyin dalgalarının saat döngüsünde, işitme ve denge organlarında vb. yapılarda bulunmaktadır. Bizim bu çalışmamız, öncelikle “Altın oran”ın insan vücuduyla ilişkilerine dair bilgileri derlemek ve mevcut literatür araştırmalarını ortaya koymayı amaçlamaktadır.

Anahtar kelimeler: Altın oran, altın sayı, insan vücudu, Fibonacci dizisi 


\section{GíRiș \\ Altın Oranın Tanımı ve Tarihçesi}

Phi sayısı olarak da bilinen Altın oran özel değerler ve estetik öneme sahip matematiksel bir değerdir. Evrendeki birçok şey örneğin insan bedeni, salyangoz kabukları, gezegenlerin yörüngesi bir oran etrafında işlenmiştir. İlahi oran ve altın dikdörtgenler antik mimari ve sanatta da karşımıza çıkmaktadır. Altın oranın estetik ve uyum için bir tasarım aracı olduğuna inanılmaktadır. İstatistiksel veriler, halkın istemeden veya farkında olmadan Altın Kesit'e (Altın oran) yaklaşan oranlara tercih verdiğine işaret etmektedir (9).

İnsanlık tarihinde bazı kavramlar ve figürler oldukça önemlidir. Fibonacci sayı dizisi olarak bilinen ve Leonardo Fibonacci tarafindan bir problemin çözümü sırasında bulunan sayılar ve sonrasında ortaya çıkan formüllere dayanan rakamlar bunlardan biri olarak gösterilebilir. Ünlü bir ortaçağ matematikçisi olan Pisa Leonardo doğanın ve insanın matematiksel yönlerinin anlaşılmasında oldukça önem yaratan açıklamalar yapmıştır. Bu açıklamalara dayanarak Fibonacci sayı dizisi 1, 1, 2, 3, 5, 8, 13, 21, 34, 55, 89, $144, \ldots$ olarak kendinden önce gelen iki sayının toplamı șeklinde ilerlemekte ancak bu kurala ilk iki sayı dahil edilmemektedir. Bu sayı dizisinde yer alan sayılar kendilerinden sonra gelen sayıya bölündüğünde $(1 / 1,1 / 2,2 / 3,3 / 5,5 / 8, \ldots$ gibi) $1,000,0,500,0,666,0,600,0,625,0,615,0,619,0,617,0,618,0,617, \ldots$ şeklinde ilerlemekte ve bu işlem sonsuza devam ettirilirse 0,618 sayısına giderek yaklaşmaktadır. Diğer taraftan, sayı dizisi içinde bir sayı kendisinden önce gelen sayıya bölündüğünde ise sonuç: 1,618 rakamına sürekli yaklaşmaktadır. Başta matematik ve fizik bilimcilerinin olmak üzere birçok bilim insanın, yıllar boyu ilgisini çeken ve araştırmalara konu olan bu rakama "altın oran", "kutsal oran", "mükemmel oran" gibi isimler verilmekte ve Greek alfabesindeki Phi Ø ile gösterilmektedir(15). Matematikçi Mark Barr altın oranı sembolize etmek için Yunan heykeltıraş Phidias'ın ilk harfleri olan "Phi (Ø)" ifadesini kullanmayı önermiş ve kabul görmüştür. Altın oran yaklaşık 2400 yıl boyunca batılı entelektüelleri de etkilemişsir $(4,9,18)$.

Eski Yunanlı Pythagoras ve Euclid'den, ortaçağ İtalyan matematikçi Leonardo Pisa ve Rönesans astronomu Johannes Kepler'den Oxford fizikçi Roger Penrose gibi günümüzün bilimsel figürlerine kadar her yaştan en büyük matematiksel zihinler altın oran konusuna özel ilgi göstermişlerdir. Ancak altın orana ilgi sadece matematikçilerle sınırlı kalmamıştır. Biyologlar, sanatçılar, müzisyenler, tarihçiler, mimarlar, psikologlar ve hatta mistikler altın oranın her yerde bulunmasının ve cazibesinin temelini tartışmışlardır. Eski Yunan matematikçiler ilk olarak, geometride sık sık ortaya çıktığı için altın oranı incelemişlerdir. Bir çizginin "aşırı ve ortalama oran" (altın bölüm) olarak bölünmesi, düzenli pentagramların ve beş köşeli pençelerin geometrisinde önemli olduğunu vurgulamışlardır. Yunanlılar genellikle bu kavramın keşfini Pythagoras'a ya da onun takipçilerine atfetmişlerdir(17).

Eşit büyüklükte iki karenin yan yana gelmesi ile bu iki kareye bitişik olacak şekilde büyük tek bir kare ve çizilen üç kareye bitişik bir kare daha eklenirse oluşan bu kareler numaralandırıldığında Fibonacci Dikdörtgenine ulaşııır $(4,13)$. Bu dikdörtgenin kenarlarının birbirine oranı da altın oranı vermektedir. $\mathrm{Bu}$ kareler çeyrek daireler oluşturacak şekilde köşelerinden birleştirilirse oluşan şekil doğada örnekleri bulunan bir spiral halini almaktadir.

Sanat ve mimaride yer alan eserler incelendiğinde altın oranı veren birçok eser bulunmaktadır. Eski Yunan Mimarisinden Leonardo Da Vinci, Raphael, Rubens, Boticelli gibi ünlü ressamlar da resimlerinde Altın oranı kullanmışlardır. Leonardo Da Vinci' ye ait olan "The Annonciation" adlı tablonun belli bir oran dahilinde yapıldığ 1 bilinmektedir. Leonardo ve çağdaşlarının o dönem sadece resim ve mimari ile uğraşmadıkları, çok yönlü, matematik, fizik gibi dallarla da yakından ilgili oldukları düşünüldüğünde bunu tablolarına yansıtmaları şaşırtıcı bulunmamıştı. Yaptıkları tabloların belli noktalarından dikey ve yatay olmak üzere iki çizgiyle kesilecek olsa kenarlarda oluşan oranın 1/1.618 olduğu görülmektedir. Günümüzde ve geçmişte resim yapma tekniğinde altın üçgen, dikdörtgen ve çokgenler sıkça kullanılmaktadır (4). Altın oran kullanımına özellikle eski Yunan ve Mısır mimarisinde sıkça rastlanmaktadır. Piramitler ve Gotik Katedrallerin cephe düzeni hem kendi içlerinde bu kurala uymakta hem de birbirleri arasında bu orana uyan spiral içinde belli noktalarda konumlandırıldıkları görülmektedir. Günümüzde ise bu orana uyan ünlü yapılar arasında Birleşmiş Milletler Binası bulunmaktadır $(2,13)$.

Bunun dışında Fibonacci Sayı Dizisi'nin ve altın oranın; şiir, müzik notaları, ekonomi gibi sanatın farklı alanlarında da kullanıldığı bilinmektedir. Ayrıca altın orana doğada bitki yapraklarında, tohumlarında, çiçek yapraklarında, çam kozalaklarında ve deniz kabuklarında da rastlanılmaktadır.

Altın orana bağlı olarak tasarlanmış yapıtların insanlar tarafindan ilgi çekici olması, kusursuz olarak kabul edilmesi, her zaman güzel olarak yorumlanması ve değerli bulunması belki de kendinden bir parça olarak bu eserlere bakmasındandır. Bir başka deyişle bu eserler kişi tarafindan doğal olarak kabul edilmektedir. Aslında bu tasarımların altın orana uygun olarak tasarlandığı baştan söylenmese bile, çekici

14 | $P$ a g e 
ve güzel olarak değerlendirilmesi bu doğal yapıdan kaynaklanmaktadır. İnsanın doğasında var olan anatomik yapıya ait antropometrik ölçümlere paralel olarak yapılan tasarımlar ve insanların kullanımına sunulan ergonometrik araçlar hem fiziksel hem de ruhsal anlamda hoş algılanması sağlanacaktır.

\section{İnsan Vücudunda Altın Oranlar}

Doğada ve sanatta sıklıkla karşımıza çıkan altın oran kavramının yaşayan birçok canlıda olduğu gibi insan vücudunda da bulunduğu bilinmektedir. İnsan vücudunda altın oran kullanımı Vitruvius olarak bilinen Marcus Vitruvius Pollio'un kullandığı oran kurallarında net olarak görülmektedir. Vitruvius Adamı, Da Vinci'nin günlüklerinden birinde bulunan eskizlerden biridir. Marcus Vitruvius Pollio'nun (MÖ.80-15) "De Architectura" adlı eserinden esinlenerek bu oranları ortaya çıkarmıştır. Venedik'te bulunan Gallerie dell'Accademia'da sergilenen, bilim ve sanat eseri olarak bilinen ve iç içe geçmiş bir çember ve karenin ortasına çizilmiş, uzuvları açık ve kapalı pozisyonda üst üste geçen bir çıplak erkeği betimlemektedir. Bu resimde Altın Oranlar dairelerle bölümlenerek gösterilmiştir ve Göbek-diz arası / Diz-ayak ucu arası ve Göbek-baş ucu arası mesafe / Omuz hizasından baş ucuna olan mesafe oran değerlerinin altın oranı verdiği bilinmektedir. Ayrıca Vitruvius Adamı'nın boyunun, göbeğin yüksekliğine oranının altın oran değerinde olduğu gösterilmiş̧tir. $\mathrm{Bu}$ oransal değerleri Leonardo gibi birçok sanatçının kullandığı ve antropometrik verilere bağlı kalarak çizimlerini gerçekleştirdikleri bilinmektedir(6). Aynı zamanda Dürer edinmiş olduğu bilgileri 1528 yılında çizimlerini yaptı̆̆ "İnsan Oranı Üzerine Dört Kitap” (Four Books on Human Proportion) adlı eserinde toplamışıtır(20).

İnsan vücudunda altın oran kavramının varlığını araştırmaya yönelik çalışmalar sonrasında bilime sunulmuş bilgileri alt başlıklar halinde inceleyelim.

\section{Yüz, Ekstremiteler ve Gövdede Altın Oran}

Antik çağda yapılan çalışmalarında ideal insan ölçüsü ' boy uzunluğunun göbekten ayak uçlarına olan uzunluğa oranı, göbekten ayakuçlarına olan uzunluğun göbekten başucuna olan uzunluğa olan oranına eşit" şeklinde tanımlanmıştır. Bu tanımı ele aldığımızda sonuç yine mükemmel orana varmaktadır (5). El işaret parmağının şekline bakarak dahi altın oranı görebilmek mümkündür. İşaret parmağının her bölümü bir öncekinden 1,618 oranında büyüktür ve her bölüm 2, 3, 5, 8'e yani ardışık Fibonacci sayılarına karşılık gelmektedir. Parmaklar 3 bölümden oluşur. Her elimizdeki 5 parmaktan sadece 8'i altın orana göre boğumlanmıştır ve 2, 3, 5 ve 8 Fibonacci sayılarına uymaktadır(3).

Ayrıca vücut uzunlukları için de aşağıda verilen oranların 1,618 değerine yakın olduğu kabul edilmektedir(14).

Diz uzunluğu / dizden bele kadar olan uzunluk,

Vücut boyu / bacak boyu,

Vücut boyu / kol altı beden boyu,

Tam kol boyu (boyun-parmak ucu) / dirsek-boyun aras1,

Göbek-omuz aras1 / göbek-bel aras1,

Parmak ucu - omuz/parmak ucu - dirsek,

El bileği-dirsek arası / parmak ucu-dirsek arası

Yüz bölgesinde antropometrik ölçümler sonrasında belirlenmiş altın oranlar şunlardır(10):

Çeneden alın bitimine / alın bitiminden saç bitimine,

Üst çenedeki ön iki dişin enlerinin toplamı / dişlerin boyları,

Göbekten boyuna / boyundan saç bitimine,

Yüzün uzunluğu / yüzün genişliği,

Dudak - kaşların birleşim yeri arası / burun boyu,

Yüzün boyu / çene ucu - kaşların birleşim yeri arası,

Ağız boyu / burun genişliği,

Burun genişliği / burun delikleri arası,

Göz bebekleri arası / kaşlar arası.

İnsan sağlığı bu belirtilen yüz oranlarından etkilenebilmektedir. Anatomik yapı olarak, uzun yüzleri olan kişilerin nefes alma problemleri daha fazladır ve uyku apnesi yaşayabilmektedirler. Daha kısa yüzleri olan kişiler ise, çene eklemindeki aşırı basınç nedeniyle, anormal çene gelişmesine sahip olup, kronik baş ağrılarından yakınabilmektedirler. Çünkü çenenin anatomik pozisyonu, kan akışını kısitlayabilmektedir.

Güzellik denilen kavramın nasıl meydana çıktığı ve güzel kavramının matematik dilinde ifadesinin bulunup bulunmadığı insanların uzun zamandır yanıt aradıkları konulardandır. Yüzde altın oran, bu

15 | P a g e

www.iiste.org 
sorular karşılığında yapılan çalışmaların bir ortak ürünü olarak ortaya çıkmıştır. Yüzde birçok oran olsa da güzellik kavramını tam olarak ortaya koyan matematiksel formüller henüz mevcut değildir. Diğer taraftan yüz unsurları içinde belirlenmiş yüzde altın oran değeri 1,61803'tür ve bu oran yalnızca ideal insan yüzü için geçerlidir.

\section{Kalpte Altın Oran}

Günümüzde altın oran ve Fibonacci Sayı Dizisi'ne, kardiyovasküler sistemde büyük bir ilgi vardır. Anatomi, fizyoloji, elektrokardiyogram ve ekokardiyogram ile ilişkilendirilen, kalpte bulunan altın oranla ilgili çalışmalar bulunmaktadır. Henein ve arkadaşları kalp pillerinde altın oran ve Altın Açının potansiyel varlığını vasküler parametreler ile ekokardiyografik yöntem kullanarak 30 sağlıklı İsveç ve 30 sağlıklı Çinli deneğin sol ventrikülün (LV) çapraz ve dikey boyutlarını ekokardiyografik olarak ölçmüşlerdir. Beklendiği gibi transvers ve sagittal boyutlarının $0,5 \mathrm{~mm}$ ve $8 \pm 1 \mathrm{~mm}$ olduğu bulunmuş ve boyutların oranı (LV oranı) her iki grupta da sabit altın oranla aynı olan 1.618 olarak ifade edilmiştir. Aynı zamanda, araştırmacılar LV oranının hastalığın ciddiyetine karşılık gelen kalp yetmezliği ayarında önemli bir değişiklik gösterdiğini test etmiş ve bu oranın, hafif ve son dönem kalp yetmezliği olan hastalarda sırasıyla 1.64 ve 1.4 civarında bulunmuş; bu muhtemelen ikinci grupta amore çarpıcı bozulma olduğunu (Bu hastalarda daha geniş bir yapısal yeniden şekillenme, daha globoid bir LV paternine yol açtığından) göstermiştir. Bu bulgular, normal erişkinlerde astral anüler boyutların ve işlevlerin büyük ölçüde ilahi estetiğe uyduğunu ve bu yapının genişlemesinin her zaman işlevsel mitral yetersizliğini belirleyen altın orandan anlamlı bir sapmanın eşlik ettiğini göstermektedir(11). Bu varsayım, triküspid kapak ve muhtemelen diğer kardiyak kapak yapıları için de geçerlidir. Ayrıca, kalp yetmezliği olan hastalarda LV'nin normal değerden belirgin bir şekilde sapmış olan genel sağ kalım oranları, 3 yıllık izlemde sadece\% 50 civarında kalmaktadır. Bu durum kalp yetmezliği hastalarında altın oranın prognostik önemini düşündürmektedir (11).

Henein ve arkadaşlarının çalışmasında kalbin ve sağ taraflı yapıların büyük arterleri altın orana çarpıcı bir benzerlik sergilediği gösterilmiştir. Bu çalışmada sağ kalp yetmezliği olan bireyler(n = 19) ve sağlıklı bireylerin $(\mathrm{n}=16)$ sağ ventrikül çıkış ve giriş yolları arasındaki anatomik açılar karşılaştırılmıştır (11). Giriş yolu ve çıkış yolu devamlılığı açısı normal kişilerde ve sağ kalp yetmezliği olan hastalarda sırasıyla $138 \pm 4^{\circ}$ ve $160 \pm 4^{\circ}$ idi (26). Diğer bir deyişle, bu iki eksen arasındaki açı normal olarak kötüleşen sağ ventrikül (ve yapısal yeniden şekillenme) ve pulmoner hipertansiyon (26) ile paralel olarak bu değerden olası adım adım sapma ile Altın Açı’ya (137.5 ${ }^{\circ}$ ) uymaktadır. Aynı çalışmada, sağlıklı kontrollerin pulmoner gövde ile ortalama artı açıları $139 \pm 3^{\circ}$, proksimal asenkron aortun neredeyse Altın Açı'ya uyduğu süreklilik gösterdiği bulunmuştur (26). Aortik ve pulmoner arterler arasındaki boşluğun, esasen bu arterlerdeki potansiyel basınç aktarımına karşı koyan, sağ ventriküler afterload'ta önemli artışlara yol açan kutsal estetiğin bir tezahürü olarak ortaya çıktığ 1 görünmektedir(11).

Ek olarak Yetkin ve arkadaşları, 462 kişilik bir çalışmada, ayaktan izlem ile değerlendirilen kan basıncının parametreleri altın orana uygunluk gösterdiğini bulmuşlardır(27). 24 saatlik, gece ve gündüz kayıtlarında diyastolik ve sistolik basınç seviyelerinin ortalama değerleri (DBP ve SBP) yanı sıra atım basınc1 (PP) (SBP-DBP olarak tanımland1) SBP/DBP ve DBP/PP'ye dönüştürülmüştür(27). Bulgular değerlendirildiğinde SBP/DBP ve DBP/PP'nin yalnızca gecelik (24 saatlik veya gündüz değil) oranları, sırasıyla 1.64 ve 1.62 değerleri ile gösterilen altın oran ile çarpıcı bir uyum gösterdiği görülmüştür(27). Gibson ve arkadaşları miyokard enfarktüsü sebeplerini araştırmışlardır(8). Çalışmalarına, Fibonacci Dizisinin, theejor epikardiyal arterlerindeki suçlu lezyonlarının yerlerinde kendini gösterebileceği ön hipoteziyle başlamışlardır. $\mathrm{Bu}$ çalışmada, tüm koroner arterlerin $(15.3 \mathrm{~cm})$ medyan uzunluğunun 4.236'ya bölündüğünü bildirmişlerdir. Fibonacci Dizisi 2,618 x 1,618 veya 2,618 / 0,618'e eşit, 3.62 cm'lik bir öngörülen değerle (koroner ostiumdaki toplam mesafenin \% 24'ü olarak ortaya çıkmıştır. İlginç olarak, miyokard enfarktüsü sebebinin koroner arter çıkış yerinden (\% 24.7) $3.78 \mathrm{~cm}$ aşağ $\%$ olduğu ve tahmin edilen değerle hemen hemen aynı olduğu bulunmuştur. Bu çalışma aynı zamanda Fibonacci Dizisi ile korpus lezyon yerinin koroner arterler arasındaki dağılımını ortaya çıkaran ilk çalışma olarak kabul edilmiştir(24). Bu organizasyon örneği, doğadaki dallanma şekillerinde Fibonacci Dizisinin görünümü nedeniyle optimum miktarda güneş ışığı alan çeşitli dallanma bitkileri ile çarpıcı bir benzerlik göstermektedir.

Benzer bir şekilde, Ashrafian ve ark. koroner arteriyel dallanma sisteminin yapısının ağaçların yaprak dallanma paternine tam bir analoji olduğunu da öne sürmüştür(1). Çalışmada 36 memeli türü araştırılarak kardiyak çapların 13 ana koroner dalın çaplarının toplamına oranının altın orana paralel olduğu görülmüştür(21). Araştırmacılar Fibonacci Serilerinin, koroner arter hastalığının yeni biyomatematiksel modellerinin kurulması ve miyokard metabolizma haritalarının geliştirilmesi ile koroner arter hastalığının geometrik ve bölgesel özelliklerinin tahmini için klinik değeri olduğunu önermişlerdir(1). Dahası, bu çığır açan yaklaşımlar, klinik ortamda teşhis edici verimi arttırmak için nihai hedefi olan

16 | P a g e 
manyetik rezonans görüntüleme(MRI), miyokard perfüzyon sintigrafisi ve bilgisayarlı tomografi(BT) de dahil olmak üzere çeşitli tanı araçlarına dahil olma potansiyeline sahip olarak belirtilmektedir(1). Bir başka çalışmada, fetal yaşam süresince kardiyak fonksiyonların olgunlaşmasında altın oran olduğu ifade edilmiştir. Gebeliğin 20. haftasında gelen 159 sağlıklı fetusta haftalık $1.6 \mathrm{~mm} / \mathrm{s}^{\prime}$ lik bir artış olduğu bildirilmiştir(7, 14). Kalp sistolü ve diyastolüne dayalı kardiyolojik bir bakış açısında, sistolik faz tipik olarak R dalgasının tepesinden T dalgasının sonuna kadar olan zaman aralığı ve bu fazın R-R aralığından çıkartılması (bir döngü, sistolik artı diyastolik fazlar) bir yüzeydeki diastolik zaman aralığını verir. Araştırmacılar 162 sağlıklı, gönüllü popülasyonda sistol ve diyastoldeki altın oranı araştırmış ve çalışma sonucunda diastolik/sistolik ve RR/diastolik zaman oranı aralıkları sırasıly 1.611 ve 1.618 olarak bulmuş ve kardiyak fazlarla altın oran arasında yakın bir uyum olduğunu ifade etmişlerdir (14).

\section{Uterusta Altın Oran}

Uterusun anormal boyutlarının hastalıklar veya disfonksiyonların saptanması için iyi bir referans olabileceği düşünülmektedir. Örneğin, uterus miyometriyal asimetri, adenomyoz varlığının bir belirleyicisidir. Ayrıca, uterusun orantısızlığı miyometrial disfonksiyonu yansitabilir ve böylece subfertilite ile ilişkili olabilir. Her ne kadar ergenlikten önce kızlar için uterus uzunluğu ve hacmi için normatif veriler tanımlanmış olsa da, diğer yaş grupları için uterus oranları ile ilgili veriler sınırlıdır (22). Yapılan bir çalışmada yaş aralığı 1-91 arasında olan 5466 normal (gebe olmayan) uterus ölçümleri alınmış, ortalama uzunluk, 40 yaşında $72 \mathrm{~mm}, 80$ yaşında $42 \mathrm{~mm}$ olduğu bulunmuştur. Ortalama uzunluk/genişlik oranı doğumda 1.857, 91 yaşında 1.452'ye düşmüştür. 21 yaşında, ortalama oran 1.618, yani altın orana eşit bulunmuştur. Artan gebelik sayısının bu oranları etkilediği ifade edilmektedir.

Yapılan bir çalışmada uterus'un bir kadının ömrü boyunca değişim göstermekle beraber, uzunluk, ortalama $7 \mathrm{~cm}$ olup, 40 yaşından sonra menopoz dönemi ve östrojen eksikliğine bağlı olarak azalmaktadır. Gebelik sayısının artması ile uterus uzunluğu da artmakta ve bu farklılık yaşam boyunca devam etmektedir. Ayrıca uterusun yaşla birlikte daha fazla yuvarlaklaştığ oranı 1.857 'den 1.452 'ye düş̧üğü ancak bu durumun 58 yaş ve üstü kadınlar için geçerli olmadığı ifade edilmiştir. Bu sonuç, hiç doğum yapmamış kadınlarda uterusun daha kısa olduğu değil, daha dar hale geldiğini düşündürmektedir. Sonuç olarak ortalama uzunluk/genişlik oranının 21 yaşında 1.618 olarak bulunduğu için, uterus boyutları ile optimal doğurganlık arasında bir ilişki olduğu söylenebilmektedir.

\section{Genomda Altın Oran}

İnsan vücudunda, fiziksel varlı̆ğn temelini oluşturan insan genomunda Fibonacci Dizisi, fraktallar ve insan genomu arasındaki potansiyel ilişki ilk olarak 1982'de Benoit Mandelbot tarafından incelenmiştir. Sonuçta DNA ve organizasyon modelinin fraktallar olarak ortaya çıkan bir yapı oluşturduğu ifade edilmiştir $(18,25)$. On yıl sonra; Fibonacci Dizileri ve altın oranlarla güçlü bir şekilde bağlantılı bir organizasyon paterni ile birlikte fraktal bir eğilimi barındırdığı insan genomik yapısının olduğu da gösterilmiştir $(17,18)$. Son olarak, Yamagishi ve arkadaşları tüm genomik yapı boyunca Fibonacci Serilerinin varlığını ortaya koyan kanıtları doğrulamışlardır $(18,25)$. DNA'nın sahip olduğu heliks yapısının boyu 34 Angstroms, eni 21 Angstroms olarak ölçülmüştür. 21 ve 34 sayıları Fibonacci Dizisinde ardışık sayılar olarak yer almaktadır.

\section{Akciğerlerde Altın Oran}

Goldberger çalışmasında, akciğer anatomik yapısındaki altın oranın varlığını ortaya koymuştur(9). Bronşların bir özelliği, asimetrik olmasıdır. Örneğin, soluk borusu biri uzun(sol) diğeri kısadır(sağ). Bu asimetrik bölünme, bronşların sonraki alt bölümlerinde de altın oran belirttiği bilinen

Fibonacci Dizisine benzeyecek şekilde devam etmektedir. Bütün bu bölünmelerdeki uzun bronşların uzunluğunun kısalarınkine oranının her zaman altın oran değerini (1.618) verdiği belirlenmiştir. Hoşten ve Topçu bronkoskopi uygulamaları sonrasında bronş ağacındaki dizilimin torasik anestezi ve anestezistler için önemli olduğunu ifade etmişlerdir(12).

Goldbeger ve West (9) yaptıkları çalışmada akciğerlerdeki asimetrik bronşiyal ağın, Weibel's Data (23) yöntemini kullanarak bir fraktal belirttiğini bulmuştur. Bu çalışmada öne attıkları fikirlerin doğruluğunu araştırmak üzere; iki yetişkin erkek birey, iki erkek köpek, bir dişi sıçan ve bir dişi hamsterın silikonlanmış akciğerini kullanarak morfometrik ölçümler yapmış olan Raabe'nin (19) verilerini kullanmışlardır. Bu çalışmada, a(kısa) ve b(uzun) olan bronşu temsil etmiş ve yaptıkları ölçümlerde b/a (uzun bronş uzunluğu/kisa bronş uzunluğu) ve $(\mathrm{a}+\mathrm{b}) / \mathrm{b}$ (toplam bronş uzunluğu/uzun bronş uzunluğu) değerlerinin birbirlerine eşit çıktığını ve bunların da $(1+\sqrt{5}) / 2$, yani altın oran değerine eşit olduğunu belirtmişlerdir. $\mathrm{Bu}$ asimetrik bölünmelerin, kendinden önceki 2 sayının toplamı şeklinde: $1,1,2,3,5,8,13,21,34 \ldots$ diye ilerleyen Fibonacci Dizisi gösterdiği de ifade edilmiştir. Çalışmanın sonunda 
yaptıkları detaylı ölçüm ve karşılaştırmalarla deneyi uyguladıkları tüm canlılarda sonucun aynı olduğunu ve bronşiyal ağaçtaki ölçülerin her zaman altın oranı verdiğini açıklamışlardır.

\section{Beyinde Altın Oran}

Rus fizyolog Sokolov beyin aktivitesinde altın oran düzeninin varlığını ortaya koymuştur. Beynin her durumuna karşılık gelen belirli elektrik salınım frekansları(beyin ritimleri) 8 ila 13 hertz arasında olan en sert ritim türü a-ritmidir. 14 - 35 hertz arasında olan b-ritim zihinsel aktiviteye, 0,5-4 hertz frekans1 ile en zayıf salınımlar ise D-ritmine karşılık gelir. Herhangi bir sorun ya da tehlike hissinin ortaya çıkması durumunda, 4'den 7 hertz'e kadar salınım frekansları ile sözde q-ritim ortaya çıkar. Farklı ritimler için beynin sınırlayıcı salınım frekanslarının değerleri hariç, diğer özelliklerle de karakterize edilen frekanslar vardır. Bunlardan biri ekstrem frekansların ortalama geometrik değeridir. Ortalama geometrik frekans, frekans bandını yüksek frekans ve düşük frekanslı alanlara böler. Bu frekans bantlarının oranı, verilen dalga için bir sabittir ve beyin değişmezidir. Araştırmacı, zihinsel aktiviteye karşılık gelen b-ritmi için bu değişmezin altın oranla örtüştüğünü keşfetmiştir. Diğer ritimler için invaryantlar (değişmezler) klasik altın orandan farklıdır fakat aynı zamanda karakteristik sayıları 1,324 (q-ritim için), 1,272 (a-ritim için), 1,232 (D-ritim için) gibi altın orana yakın değerler olduğu için bunlara da genelleştirilmiş altın orandan bahsedilmektedir.

\section{SONUÇ}

Altın oran doğada sıklıkla karşımıza çıkmakta ve yaşayan canlıların birçoğunun anatomik yapısı bu oransal sisteme uyum göstermektedir. Özellikle insan yapısı incelendiğinde bu oranın örneklerine oldukça fazla rastlanmaktadır. Diğer yandan çevremizde ve kendimizde doğal olarak bulunan bu oransal tasarım, birçok sanatçının eserinde de kullanılmakta ve bu eserler insanlar tarafından büyük ilgi görmektedir. Bu ilginin sebebi ise insanların kusursuz kabul edilmesi, güzel olarak değerlendirilmesi ve belki de kendinden bir parça olarak bu eserlere bakmasındandır. Bir başka deyişle bu eserler bilincimizde doğal olarak kabul edilmekte, yapılan tasarımların bu orana göre yapıldığı baştan söylenmese bile çekici ve güzel olarak değerlendirilmesi bu doğal yapıdan kaynaklanmaktadır. Öyle ise zaten doğası altın orana uyumlu olan insan anatomisinden alınacak antropometrik verilere bağlı tasarımlar ile insan kullanımı için gerçekleştirilecek eserlerin; hem fiziksel olarak ergonomik, hem de ruhsal açıdan güzel olarak algılanması sağlanmış olacaktır. Aynı zamanda klinik ve cerrahi yaklaşımlarda da insan vücudunda var olduğu bilinen altın oran değerlerinin göz önünde bulundurulmasının faydalı olabileceği düşüncesindeyiz.

\section{Kaynakça}

[1] Ashrafian H., Athanasiou T. Fibonacci series and coronary anatomy Heart Lung Circ., 20, 7, 2011 : 483-484.

[2] Bakım S. Fibonacci Dizisi Ve Altın Oranın Müzikte Kullanımının İncelenmesi. (yüksek lisans tezi, Selçuk Üniversitesi, 2014)

[3] Bergil M.S. Doğada/Bilimde/Sanatta, Altın oran, Arkeoloji ve Sanat Yayınları, 2.Basım, 1993: 87.

[4] Çağlarca S. Altın oran. İstanbul: İnkilap Kitabevi,1993.

[5] Duru A. İşleyen T. Matematik ve Sanat, Kazım Karabekir Eğitim Fakültesi Dergisi, 1.1 Coxeter, H.S.M, Escher: Art and Science, Elsevier Science Publishers, 1986.

[6] Elam, K. Geometry Of Design Studies in Proportion and Composition, Princeton Architectural Press, New York, 2001.

[7] Gardiner H.M., Pasquini L., Wolfenden J., et al. Myocardial tissue Doppler and long axis function in the fetal heart. Int J Cardiol. 113(1):39-47, 2006.

[8] Gibson C.M., Gibson W.J., Murph S.A., et al., Association of the Fibonacci cascade with the distribution of coronary artery lesions responsible for ST-segment elevation myocardial infarction, Am J. Cardiol. 92:595-597,2003.

[9] Goldberger A. L., et al., Bronchial Assymetry and Fibonacci Scaling, Experientia, 41, 1985:15371538

18 | $P$ a g e

www.iiste.org 
[10] Hastürk, E . Antropometrik Verilerde Altın Oran. Mesleki Bilimler Dergisi (MBD), 3,2, 2015: 173177. Retrieved from http://dergipark.gov.tr/mbd/issuo

[11] Henein M.Y., Zhao Y., Nicoll R., et al. , The human heart: application of the golden ratio and angle, Int. J. Cardiol. 150: 239-242, 2011.

[12] Hoşten T., Topçu S., Anestezistler için bronkoskopik anatominin önemi, Tüberküloz ve Toraks; 59, 416-426, 2011.

[13] http://efdergi.yyu.edu.tr YYÜ Eğitim Fakültesi Dergisi (YYU Journal Of Education Faculty),2016,Cilt:XIII, Sayı:I,360-382

[14] https://matematiksevgisi54.tr.gg/vucudumuzda-altin-oran.html

[15] Knott, R., kişisel web sitesi 1996. http://www.mcs.surrey.ac.uk/Personal/R.Knott/ Fibonacci Ekim 2004,

[16] Perez J.C., Codex Biogenes: Les 13 Codes De L’adn. Médecine \& Sciences, 2009.

[17] Perez J.C., Chaos, DNA, and Neuro-computers: a golden link: the hidden language of genes, global language and order in the human genome Specul. Sci. Technol., 14, 336-346, 1991.

[18] Persaud-Sharma D., J.P. O\&apos;LearyFibonacci series, golden proportions, and the human biology, Austin. J. Surg., 2,5:1066, 2005.

[19] Raabe O. G., Yeh H. C., Schum G.M., Phalen R.F., Tracheo-bronchial geometry: human, dog, rat, hamster, Lovelace Foundation for Medical Education and, Albuquerque, N.M. 1976.

[20] Tekkanat, N., Altın Oran'ın Kaynakları ve Sanata Yansıması, Akdeniz Üniversitesi Sosyal Bilimler Enstitüsü, Yüksek Lisans Tezi, Antalya, 2006.

[21] Thüroff J.W., Hort W., Lichti H., Diameter of coronary arteries in 36 species of mammalian from mouse to giraffe, Basic Res. Cardiol., 79: 199-206,1984 .

[22] Verguts J., Ameye L., Bourne T., Timmerman D., Normative data for uterine size according to age and gravidity and possible role of the classical golden ratio. Ultrasound Obstet Gynecol, 42: 713 717, 2013.

[23] Weibel, E.R., Morphometry of the Human Lung, p. 110. Academic Press, New York, 1963.

[24] Yalta K., Ozturk S., Yetkin E., Golden Ratio and the heart: A review of divine aesthetics, International Journal of Cardiology, $214: 107-112,2016$.

[25] Yamagishi M.E., Shimabukuro A.I., Nucleotide frequencies in human genome and Fibonacci numbers Bull. Math. Biol., 70: 643-653, 2008.

[26] Yetkin E., Celik T., Arpaci M., Ileri M., Left ventricular diameters as a reflection of "extreme and mean ratio", Int. J. Cardiol. 198: 85-86, 2015.

[27] Yetkin E., Topbaş U., Yanik A., Yetkin G., Does systolic and diastolic blood pressure follow Golden Ratio? Int. J. Cardiol, 176,3:1457-1459. , 2014 